\title{
1,3-Diphosphacyclobutadiene as a Ligand in Binuclear Manganese Carbonyl Derivatives: Role of The Ring Phosphorus Atoms
}

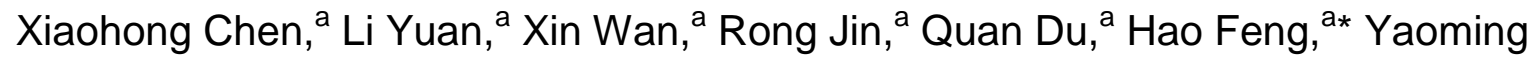 \\ Xie, ${ }^{b}$ and R. Bruce King ${ }^{\star b}$ \\ ${ }^{a}$ School of Sciences and Research Center for Advanced Computation, Xihua \\ University, Chengdu, China 610039 \\ ${ }^{b}$ Department of Chemistry and Center for Computational Quantum Chemistry \\ University of Georgia, Athens, Georgia 30602, USA \\ E-mail: Fenghao@mail.xhu.edu.cn; rbking@chem.uga.edu
}

\begin{abstract}
The binuclear 1,3-diphosphacyclobutadiene manganese carbonyls $\left(\mathrm{Me}_{2} \mathrm{C}_{2} \mathrm{P}_{2}\right)_{2} \mathrm{Mn}_{2}(\mathrm{CO})_{n}(n=6,5,4,3)$ have been investigated by density functional theory. The lowest energy $\left(\mathrm{Me}_{2} \mathrm{C}_{2} \mathrm{P}_{2}\right)_{2} \mathrm{Mn}_{2}(\mathrm{CO})_{n}(n=6,5)$ structures are found to have two mononuclear $\left(\mathrm{Me}_{2} \mathrm{C}_{2} \mathrm{P}_{2}\right)_{2} \mathrm{Mn}_{2}(\mathrm{CO})_{m}$ fragments linked by $\mathrm{P} \rightarrow \mathrm{M}$ dative bonds. The lowest energy isomers with terminal $\eta^{4}-\mathrm{Me}_{2} \mathrm{C}_{2} \mathrm{P}_{2}$ rings and $\mathrm{Mn}-\mathrm{Mn}$ bonds lie $\sim 15$ and $\sim 22 \mathrm{kcal} / \mathrm{mol}$ above these global minima for $\left(\mathrm{Me}_{2} \mathrm{C}_{2} \mathrm{P}_{2}\right)_{2} \mathrm{Mn}_{2}(\mathrm{CO})_{6}$ and $\left(\mathrm{Me}_{2} \mathrm{C}_{2} \mathrm{P}_{2}\right) \mathrm{Mn}_{2}(\mathrm{CO})_{5}$, respectively. For the $\left(\mathrm{Me}_{2} \mathrm{C}_{2} \mathrm{P}_{2}\right)_{2} \mathrm{Mn}_{2}(\mathrm{CO})_{4}$ system, singlet structures with terminal $\eta^{4}-\mathrm{Me}_{2} \mathrm{C}_{2} \mathrm{P}_{2}$ rings and formal $\mathrm{Mn} \equiv \mathrm{Mn}$ triple bonds are of comparable energies to triplet structures consisting of $\left(\mathrm{Me}_{2} \mathrm{C}_{2} \mathrm{P}_{2}\right)_{2} \mathrm{Mn}_{2}(\mathrm{CO})_{m}$ fragments linked by two $\mathrm{P} \rightarrow \mathrm{M}$ dative bonds. All of the low-energy $\left(\mathrm{Me}_{2} \mathrm{C}_{2} \mathrm{P}_{2}\right)_{2} \mathrm{Mn}_{2}(\mathrm{CO})_{3}$ structures have terminal $\eta^{4}-\mathrm{Me}_{2} \mathrm{C}_{2} \mathrm{P}_{2}$ rings and three bridging $\mathrm{CO}$ groups with short $\mathrm{Mn}-\mathrm{Mn}$ distances suggesting formal multiple bonds.
\end{abstract}




\section{Introduction}

Extension of the chemistry of sandwich compounds from bis(cyclopentadienyl)metal derivatives, such as ferrocene [1, 2], and from dibenzenemetal derivatives, such as the chromium compound $\left(\eta^{6}-\mathrm{C}_{6} \mathrm{H}_{6}\right)_{2} \mathrm{Cr}$ [3], to cyclobutadiene-metal complexes is complicated by the instability of free cyclobutadiene. However, the 1,3-diphosphacyclobutadiene ligand $\mathrm{R}_{2} \mathrm{C}_{2} \mathrm{P}_{2}$ with bulky carbon substituents $(\mathrm{R})$ such as tert-butyl is available through the dimerization of the corresponding phosphaalkynes, $\mathrm{RC} \equiv \mathrm{P}$ : on transition metal sites [4]. Thus the very stable nickel sandwich complex $\left(\eta^{4}-\mathrm{tBu}_{2} \mathrm{C}_{2} \mathrm{P}_{2}\right)_{2} \mathrm{Ni}$ with the favored 18 -electron configuration (Figure 1 ) has been synthesized by reaction of $\left(\eta^{2,2}-\mathrm{C}_{8} \mathrm{H}_{12}\right)_{2} \mathrm{Ni}$ with $\mathrm{tBuC} \equiv \mathrm{P}:[5]$. Similarly, the anionic sandwich compounds $\left[\left(\eta^{4}-\mathrm{Bu}_{2}^{\mathrm{t}} \mathrm{C}_{2} \mathrm{P}_{2}\right)_{2} \mathrm{M}\right]^{-}(\mathrm{M}=\mathrm{Co}$ [6], Fe [7]) have been synthesized by displacement of coordinated anthracene from the anions $\left[\left(\eta^{4}-\mathrm{C}_{14} \mathrm{H}_{10}\right)_{2} \mathrm{M}\right]^{-}(\mathrm{M}=\mathrm{Co}, \mathrm{Fe})$ with four equivalents of $\mathrm{Bu}^{\mathrm{t}} \mathrm{C} \equiv \mathrm{P}$ : Oxidation of the monoanions with $\left[\left(\eta^{5}-\mathrm{C}_{5} \mathrm{H}_{5}\right)_{2} \mathrm{Fe}\right]^{+}$gives the corresponding neutral derivatives $\left(\eta^{4}-\mathrm{Bu}_{2}^{\mathrm{t}} \mathrm{C}_{2} \mathrm{P}_{2}\right)_{2} \mathrm{M}$. The neutral cobalt derivative $\left(\eta^{4}-\mathrm{Bu}_{2}^{\mathrm{t}} \mathrm{C}_{2} \mathrm{P}_{2}\right)_{2} \mathrm{Co}$ has a 17-electron configuration and a magnetic moment of $1.73 \mu_{\mathrm{B}}$ corresponding to one unpaired electron, whereas the neutral iron derivative $\left(\eta^{4}-\mathrm{Bu}_{2}^{\mathrm{t}} \mathrm{C}_{2} \mathrm{P}_{2}\right)_{2} \mathrm{Fe}$ has a 16-electron configuration and a magnetic moment of $2.74 \mu_{\mathrm{B}}$ corresponding to two unpaired electrons. These cobalt and iron sandwich compounds are potential sources of the 1,3-diphosphacyclobutadiene ligand for the syntheses of complexes of other metals through ligand transfer reactions. In addition to the sandwich compounds $\left(\eta^{4}-\mathrm{Bu}_{2}^{\mathrm{t}} \mathrm{C}_{2} \mathrm{P}_{2}\right)_{2} \mathrm{M}(\mathrm{M}=\mathrm{Fe}, \mathrm{Co})$, metal complexes with a single 1,3-diphosphacyclobutadiene ligand, are known, such as the very stable $\left(\mathrm{tBu}_{2} \mathrm{C}_{2} \mathrm{P}_{2}\right)_{2} \mathrm{Fe}(\mathrm{CO})_{3}$ (Figure 1). The latter compound is obtained by direct reaction of $\mathrm{Fe}(\mathrm{CO})_{5}$ with $\mathrm{tBuC} \equiv \mathrm{P}:$ [8]. In addition to these transition metal 1,3-diphosphacyclobutadiene complexes, substituted 1,3-diphosphacyclobutadiene dianions have been synthesized as their dilithium salts [9, 10]. They are also reagents that could be used for the synthesis of 1,3-diphosphacyclobutadiene metal complexes.

A limitation in the analogy between the cyclobutadiene ligand and the 1,3-diphosphacyclobutadiene ligand as its diphosphorus analogue is the basicity of the lone pairs on the phosphorus atoms. This limitation is particularly significant for binuclear diphosphacyclobutadiene metal complexes where separate metal atoms are available for the tetrahapto bond from the $\mathrm{C}_{2} \mathrm{P}_{2}$ ring and for dative $\mathrm{P} \rightarrow \mathrm{M}$ bonds from the ring phosphorus atoms. The basicity of the phosphorus atoms in $\left(\mathrm{tBu}_{2} \mathrm{C}_{2} \mathrm{P}_{2}\right) \mathrm{Fe}(\mathrm{CO})_{3}$ is indicated by the synthesis of the chromium pentacarbonyl complex $\left[\mathrm{tBu}_{2} \mathrm{C}_{2} \mathrm{P}_{2} \rightarrow \mathrm{Cr}(\mathrm{CO})_{5}\right] \mathrm{Fe}(\mathrm{CO})_{3}[11]$. In addition, the sandwich compounds $\left(\eta^{4}-\mathrm{Bu}_{2}^{\mathrm{t}} \mathrm{C}_{2} \mathrm{P}_{2}\right)_{2} \mathrm{M}$ can function as bidentate chelate ligands by using a phosphorus atom from each $\mathrm{R}_{2} \mathrm{C}_{2} \mathrm{P}_{2}$ ring. In homobinuclear complexes similar bonding modes of an $\mathrm{R}_{2} \mathrm{C}_{2} \mathrm{P}_{2}$ ring to a pair of metal atoms can lead to a 
$\eta^{4}, \eta^{1}-\mathrm{R}_{2} \mathrm{P}_{2} \mathrm{C}_{2}$ ligand bridging a pair of metal atoms by bonding to one metal atom as a tetrahapto ligand using the full $\mathrm{P}_{2} \mathrm{C}_{2}$ ring but to the other metal atom as a monohapto dative ligand using only a phosphorus lone pair. In such a configuration a neutral $\eta^{4}, \eta^{1}-\mathrm{R}_{2} \mathrm{P}_{2} \mathrm{C}_{2}$ ligand functions as a six-electron donor to the pair of metal atoms.

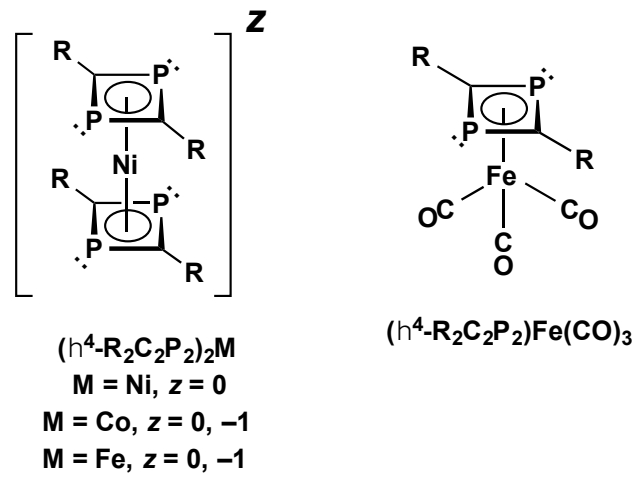

Figure 1. Some known metal complexes of the 2,4-di-tert-butyl-1,3-diphosphacyclobutadiene ligand $(\mathrm{R}=$ tert-butyl).
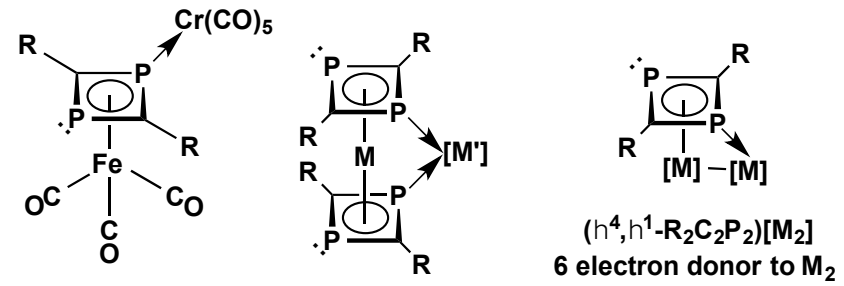

Figure 2. Modes of coordination of the ring phosphorus atoms in 1,3-diphosphacyclobutadiene ligands to transition metals. $[\mathrm{M}]$ refers to the transition metal atom surrounded by unspecified ligands other than the 1,3-diphosphacyclobutadiene ligand.

In order to assess the effects of the basicity of the ring phosphorus atoms in 1,3-diphosphacyclobutadiene metal carbonyl complexes the structures and thermochemistry of the binuclear 1,3-diphosphacyclobutadiene iron carbonyls $\left(\mathrm{Me}_{2} \mathrm{C}_{2} \mathrm{P}_{2}\right)_{2} \mathrm{Fe}_{2}(\mathrm{CO})_{n}(n=5,4,3,2)$ were studied by density functional theory [12] for comparison with the corresponding previously studied [13] binuclear cyclobutadiene iron carbonyls $\left(\mathrm{C}_{4} \mathrm{H}_{4}\right)_{2} \mathrm{Fe}_{2}(\mathrm{CO})_{n}$. Methyl rather than the bulkier tert-butyl substituents were used for this study in order to facilitate the optimizations of large numbers of starting structures. For $\left(\mathrm{Me}_{2} \mathrm{C}_{2} \mathrm{P}_{2}\right)_{2} \mathrm{Fe}_{2}(\mathrm{CO})_{5}$ a structure with a bridging $\eta^{4}, \eta^{1}-\mathrm{Me}_{2} \mathrm{C}_{2} \mathrm{P}_{2}$ ring and no iron-iron bond was found to be energetically preferred by more than $24 \mathrm{kcal} / \mathrm{mol}$ over an alternative structure with only terminal $\eta^{4}-\mathrm{Me}_{2} \mathrm{C}_{2} \mathrm{P}_{2}$ rings and an iron-iron single bond thereby indicating preferential involvement of the phosphorus lone pair. The lowest energy singlet and triplet $\left(\mathrm{Me}_{2} \mathrm{C}_{2} \mathrm{P}_{2}\right)_{2} \mathrm{Fe}_{2}(\mathrm{CO})_{4}$ structures also have at least one bridging $\eta^{4}, \eta^{1}-\mathrm{Me}_{2} \mathrm{C}_{2} \mathrm{P}_{2}$ ligand, which, in one case, is in the form of an $\left(\eta^{4}-\mathrm{Me}_{2} \mathrm{C}_{2} \mathrm{P}_{2}\right)_{2} \mathrm{Fe}(\mathrm{CO})$ sandwich bidentate 
ligand chelating to an $\mathrm{Fe}(\mathrm{CO})_{3}$ unit through two ring phosphorus atoms. In contrast to $\left(\mathrm{Me}_{2} \mathrm{C}_{2} \mathrm{P}_{2}\right)_{2} \mathrm{Fe}_{2}(\mathrm{CO})_{n}(n=5,4)$, the lowest energy structures for $\left(\mathrm{Me}_{2} \mathrm{C}_{2} \mathrm{P}_{2}\right)_{2} \mathrm{Fe}_{2}(\mathrm{CO})_{3}$ have only terminal $\eta^{4}-\mathrm{Me}_{2} \mathrm{C}_{2} \mathrm{P}_{2}$ ligands, three carbonyl groups, and an $\mathrm{Fe} \equiv \mathrm{Fe}$ triple bond. Interesting structures for the dicarbonyl $\left(\mathrm{Me}_{2} \mathrm{C}_{2} \mathrm{P}_{2}\right)_{2} \mathrm{Fe}_{2}(\mathrm{CO})_{2}$ include a structure with a $\left(\eta^{4}-\mathrm{Me}_{2} \mathrm{C}_{2} \mathrm{P}_{2}\right)_{2} \mathrm{Fe}$ sandwich ligand chelating to an $\mathrm{Fe}(\mathrm{CO})_{2}$ group and a structure with exclusively terminal $\eta^{4}-\mathrm{Me}_{2} \mathrm{C}_{2} \mathrm{P}_{2}$ ligands and a short Fe-Fe distance of $\sim 2.16 \AA$, suggesting a formal quadruple bond. Similar involvement of the phosphorus lone pair of phospholyl ligands in ligand-metal bonding was observed in the binuclear manganese and cobalt carbonyl complexes $\left(\mathrm{C}_{4} \mathrm{H}_{4} \mathrm{P}\right)_{2} \mathrm{M}_{2}(\mathrm{CO})_{n}(\mathrm{M}=\mathrm{Mn}$ [14], $n=5,4,3,2 ; \mathrm{M}=\mathrm{Co}$ [15], $n=4,3$, $2,1)$.

This paper reports a theoretical investigation of the binuclear 1,3-diphosphacyclobutadiene manganese carbonyl complexes $\left(\mathrm{Me}_{2} \mathrm{C}_{2} \mathrm{P}_{2}\right)_{2} \mathrm{Mn}_{2}(\mathrm{CO})_{n}(n=6,5,4,3)$. The analogous cyclobutadiene manganese carbonyl complexes $\left(\mathrm{C}_{4} \mathrm{H}_{4}\right)_{2} \mathrm{Mn}_{2}(\mathrm{CO})_{n}$, although not yet known experimentally, have been the subject of a previous theoretical study [16]. Some aspects of $\left(\mathrm{C}_{4} \mathrm{H}_{4}\right)_{2} \mathrm{Mn}_{2}(\mathrm{CO})_{n}$ chemistry were predicted to be very similar to the related binuclear cyclopentadienylchromium carbonyls $\left(\mathrm{C}_{5} \mathrm{H}_{5}\right)_{2} \mathrm{Cr}_{2}(\mathrm{CO})_{n}$, which are experimentally known for $n=6$ and 4 . In addition, the $\left(\mathrm{C}_{4} \mathrm{H}_{4}\right)_{2} \mathrm{Mn}_{2}(\mathrm{CO})_{n}$ structures can be related to $\mathrm{Mn}_{2}(\mathrm{CO})_{n+4}$ structures by replacing two $\mathrm{CO}$ groups on each manganese atom with a cyclobutadiene ring. However, some unusual structure types were also predicted for $\left(\mathrm{C}_{4} \mathrm{H}_{4}\right)_{2} \mathrm{Mn}_{2}(\mathrm{CO})_{n}$ derivatives. Thus an unusual low-energy triplet cluster structure was predicted for $\left(\mathrm{C}_{4} \mathrm{H}_{4}\right)_{2} \mathrm{Mn}_{2}(\mathrm{CO})_{4}$ having a central $\mathrm{C}_{4} \mathrm{Mn}_{2}$ octahedron. Other unusual $\left(\mathrm{C}_{4} \mathrm{H}_{4}\right)_{2} \mathrm{Mn}_{2}(\mathrm{CO})_{n}$ structures provide examples of agostic $\mathrm{C}-\mathrm{H}-\mathrm{Mn}$ interactions not found in the chemistry of $\left(\eta^{5}-\mathrm{C}_{5} \mathrm{R}_{5}\right)_{2} \mathrm{Cr}_{2}(\mathrm{CO})_{n}$ derivatives or even other binuclear cyclopentadienylmetal carbonyls.

\section{Theoretical Methods}

Electron correlation effects were considered by using density functional theory (DFT) methods, which have evolved as a practical and effective computational tool, especially for organometallic compounds [17, 18, 19, 20, 21, 22, 23]. Thus two DFT methods were used in this study. The first functional is the B3LYP method, which is the hybrid HF/DFT method using the combination of the three parameter Becke functional [24] with the Lee-Yang-Parr generalized gradient correlation functional [25]. The other DFT method used in the present paper is BP86, which combines Becke's 1988 exchange functional with Perdew's 1986 gradient corrected correlation functional method (P86) [26,27]. In the present study, the B3LYP and BP86 methods agree with each other fairly well in predicting the structural characteristics of the $\left(\mathrm{Me}_{2} \mathrm{C}_{2} \mathrm{P}_{2}\right)_{2} \mathrm{Mn}_{2}(\mathrm{CO})_{n}$ derivatives of 
interest. These two DFT methods also predict similar relative energies for structures with the same spin state. However, for structures with different spin states, the two DFT methods predict different relative energies. Thus B3LYP favors the high-spin state and BP86 favors the low-spin state. Reiher et al. have studied this discrepancy thoroughly and find that the true value should lie between the B3LYP and BP86 values.

All computations were performed using the double- $\zeta$ plus polarization (DZP) basis sets. The DZP basis sets used for carbon, oxygen and phosphorus add one set of pure spherical harmonic $d$ functions with orbital exponents $\alpha_{d}(C)=0.75, \alpha_{d}(O)=0.85$, and $\alpha_{d}(P)$ $=0.60$ to the standard Huzinaga-Dunning contracted DZ sets [29,30]. For hydrogen, a set of $\mathrm{p}$ polarization functions $\alpha_{\mathrm{p}}(\mathrm{H})=0.75$ is added to the Huzinaga-Dunning DZ set. The loosely contracted DZP basis set for manganese is the Wachters primitive set [31], augmented by two sets of $\mathrm{p}$ functions and a set of $\mathrm{d}$ functions, contracted following Hood, Pitzer, and Schaefer, designated (14s11p6d/10s8p3d) [32]. The geometries of all structures were fully optimized using the DZP B3LYP and DZP BP86 methods. The vibrational frequencies and the corresponding infrared intensities were determined analytically. All of the computations were carried out with the Gaussian 09 program [33], exercising the fine grid option (75 radial shells, 302 angular points) for evaluating integrals numerically [34].

In the present paper, the diphosphacyclobutadiene ligands have methyl substituents. This differs from the experimental systems, which have tert-butyl substituents in order to provide a stable $\mathrm{RC} \equiv \mathrm{P}$ : derivative to access the diphosphacyclobutadiene system [35]. In order to test this computational simplification, the relative energies of the lowest energy $\left(\mathrm{Me}_{2} \mathrm{C}_{2} \mathrm{P}_{2}\right)_{2} \mathrm{Mn}_{2}(\mathrm{CO})_{3}$ structures were compared with those of the corresponding $\left(\mathrm{tBu}_{2} \mathrm{C}_{2} \mathrm{P}_{2}\right)_{2} \mathrm{Mn}_{2}(\mathrm{CO})_{3}$ structures (Table $\mathrm{S} 30$ of the Supporting Information). In this connection the relative energies of most $\left(\mathrm{Me}_{2} \mathrm{C}_{2} \mathrm{P}_{2}\right)_{2} \mathrm{Mn}_{2}(\mathrm{CO})_{3}$ structures were shown to be comparable with those of $\left(\mathrm{tBu}_{2} \mathrm{C}_{2} \mathrm{P}_{2}\right)_{2} \mathrm{Mn}_{2}(\mathrm{CO})_{3}$ structures with the same energy ordering for both systems. We also investigated the $\omega$ B97X-D functional [36], which includes dispersion corrections (Table S30 in Supporting Information). Again the relative energies from the $\omega \mathrm{B} 97 \mathrm{X}-\mathrm{D}$ functional were found to be comparable with those from other functionals, and were especially close to the B3LYP results. Therefore, the simplified model in the present paper using methyl rather than tert-butyl substituents appears to be reasonable. 


\section{Results and Discussion}

\subsection{Molecular Structures.}

3.1.1 $\left(\mathrm{Me}_{2} \mathrm{C}_{2} \mathrm{P}_{2}\right)_{2} \mathrm{Mn}_{2}(\mathrm{CO})_{6}$. Eight low-energy singlet $\left(\mathrm{Me}_{2} \mathrm{C}_{2} \mathrm{P}_{2}\right)_{2} \mathrm{Mn}_{2}(\mathrm{CO})_{6}$ structures were found by using the B3LYP and BP86 methods (Figure 3 and Table S21 in the Supporting Information). The lowest energy $\left(\mathrm{Me}_{2} \mathrm{C}_{2} \mathrm{P}_{2}\right)_{2} \mathrm{Mn}_{2}(\mathrm{CO})_{6}$ structure $\mathbf{6 S - 1}$ consists of two $\left(\mathrm{Me}_{2} \mathrm{C}_{2} \mathrm{P}_{2}\right) \mathrm{Mn}(\mathrm{CO})_{3}$ units connected by a dative $\mathrm{P} \rightarrow \mathrm{Mn}$ bond of length $2.422 \AA$ (BP86) or $2.447 \AA$ (B3LYP). Each manganese atom is bonded to three terminal CO groups. There are one $\eta^{4}-\mathrm{Me}_{2} \mathrm{C}_{2} \mathrm{P}_{2}$ ring and one $\eta^{4}, \eta^{1}-\mathrm{Me}_{2} \mathrm{C}_{2} \mathrm{P}_{2}$ ring. The long $\mathrm{Mn} \cdots \mathrm{Mn}$ distance of $4.544 \AA$ (BP86) or $4.603 \AA$ (B3LYP) in 6S-1 clearly indicates the lack of a direct metal-metal bond. Assigning a formal positive charge to the manganese atom with a $\mathrm{P} \rightarrow \mathrm{Mn}$ dative bond and a formal negative charge to the other manganese atom gives each manganese atom the favored 18-electron configuration.

The $\left(\mathrm{Me}_{2} \mathrm{C}_{2} \mathrm{P}_{2}\right)_{2} \mathrm{Mn}_{2}(\mathrm{CO})_{6}$ structure $\mathbf{6 S - 2}$, lying $4.4 \mathrm{kcal} / \mathrm{mol}$ (BP86) or $5.3 \mathrm{kcal} / \mathrm{mol}$ (B3LYP) in energy above 6S-1, consists of an $\left(\mathrm{Me}_{2} \mathrm{C}_{2} \mathrm{P}_{2}\right) \mathrm{Mn}(\mathrm{CO})_{4}$ unit bonded to an $\left(\mathrm{Me}_{2} \mathrm{C}_{2} \mathrm{P}_{2}\right) \mathrm{Mn}(\mathrm{CO})_{2}$ unit through a $\mathrm{P} \rightarrow \mathrm{Mn}$ dative bond of length $2.068 \AA$ (BP86) or 2.063 $\AA$ (B3LYP). This $\mathrm{P} \rightarrow \mathrm{Mn}$ dative bond is $\sim 0.4 \AA$ shorter than that in $\mathbf{6 S - 1}$. The Mn $\cdots \mathrm{Mn}$ distance in 6S-2 is predicted to be a clearly non-bonding $4.786 \AA$ (BP86) or $4.803 \AA$ (B3LYP). A formal positive charge on the $\left(\mathrm{Me}_{2} \mathrm{C}_{2} \mathrm{P}_{2}\right) \mathrm{Mn}(\mathrm{CO})_{4}$ unit and a formal negative charge on the $\left(\mathrm{Me}_{2} \mathrm{C}_{2} \mathrm{P}_{2}\right) \mathrm{Mn}(\mathrm{CO})_{2}$ unit gives each manganese atom in 6S-2 the favored 18electron configuration.

The six next higher energy $\left(\mathrm{Me}_{2} \mathrm{C}_{2} \mathrm{P}_{2}\right)_{2} \mathrm{Mn}_{2}(\mathrm{CO})_{6}$ structures 6S-3 $\left(\mathrm{C}_{2}\right), 6 \mathrm{~S}-4\left(\mathrm{C}_{1}\right)$, 6S-5 $\left(\mathrm{C}_{1}\right)$, 6S-6 $\left(\mathrm{C}_{1}\right)$, 6S-7 $\left(\mathrm{C}_{2}\right)$, and $\mathbf{6 S - 8}\left(C_{2 h}\right)$, lying 15 to $20 \mathrm{kcal} / \mathrm{mol}$ above $\mathbf{6 S - 1}$, all have similar configurations (Figure 3 and Table $\mathrm{S} 21$ ).. Each $\mathrm{Mn}(\mathrm{CO})_{3}$ group is bonded to a terminal $\eta^{4}-\mathrm{Me}_{2} \mathrm{C}_{2} \mathrm{P}_{2}$ ligand. These six $\left(\mathrm{Me}_{2} \mathrm{C}_{2} \mathrm{P}_{2}\right)_{2} \mathrm{Mn}_{2}(\mathrm{CO})_{6}$ structures differ in the orientations of the $\eta^{4}-\mathrm{Me}_{2} \mathrm{C}_{2} \mathrm{P}_{2}$ rings, the planes of which are not parallel. The $\mathrm{Mn}-\mathrm{Mn}$ distances ranging from 3.0 to $3.4 \AA$ can be interpreted as formal single bonds to give each manganese atom the favored 18 -electron configuration.

3.1.2 $\left(\mathrm{Me}_{2} \mathrm{C}_{2} \mathrm{P}_{2}\right)_{2} \mathrm{Mn}_{2}(\mathrm{CO})_{5}$. Two singlet and three triplet $\left(\mathrm{Me}_{2} \mathrm{C}_{2} \mathrm{P}_{2}\right)_{2} \mathrm{Mn}_{2}(\mathrm{CO})_{5}$ isomers were found using the B3LYP and BP86 methods (Figure 4 and Table S22). The lowest energy $\left(\mathrm{Me}_{2} \mathrm{C}_{2} \mathrm{P}_{2}\right)_{2} \mathrm{Mn}_{2}(\mathrm{CO})_{5}$ structure 5S-1 consists of $\left(\eta^{4}-\mathrm{Me}_{2} \mathrm{C}_{2} \mathrm{P}_{2}\right) \mathrm{Mn}(\mathrm{CO})_{2}$ and $\left(\eta^{1}, \eta^{4}-\right.$ $\left.\mathrm{Me}_{2} \mathrm{C}_{2} \mathrm{P}_{2}\right) \mathrm{Mn}(\mathrm{CO})_{3}$ units linked by a dative $\mathrm{P} \rightarrow \mathrm{Mn}$ bond of length $2.186 \AA$ (BP86) or 2.188 $\AA$ (B3LYP) and an Mn-Mn single bond of length $3.227 \AA$ (BP86) or $3.356 \AA$ (B3LYP). This bonding scheme in $\mathbf{5 S - 1}$ gives each manganese atom the favored 18-electron configuration. 


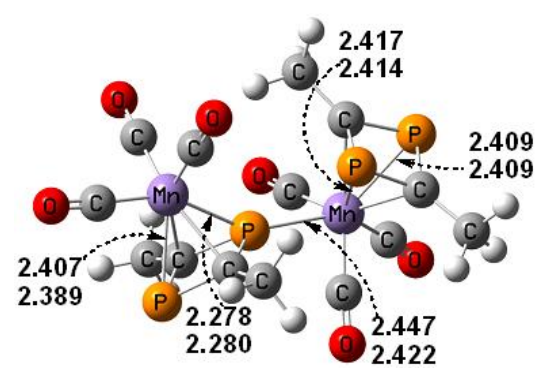

6S-1 $\left(C_{1}\right)$

$(0.0 / 0.0)$

$(0.0 / 0.0)$

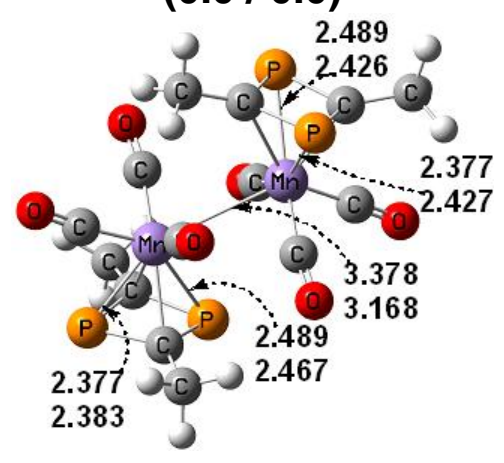

6S-4 $\left(C_{1}\right)$

(14.6/14.4)

(15.8 / 15.8)

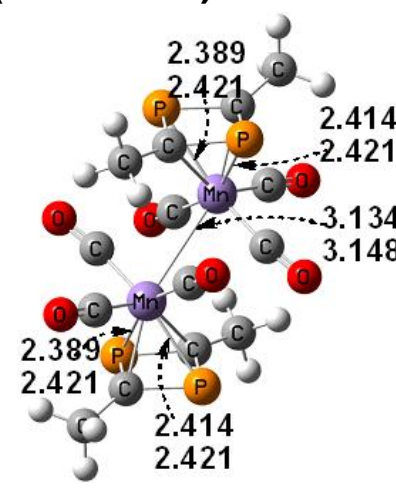

6S-7 $\left(C_{2}\right)$

(16.5 / 16.2)

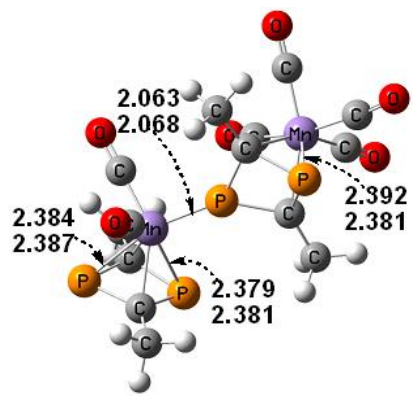

6S-2 $\left(C_{1}\right)$

(5.3 / 5.2)

(4.4 / 4.4)

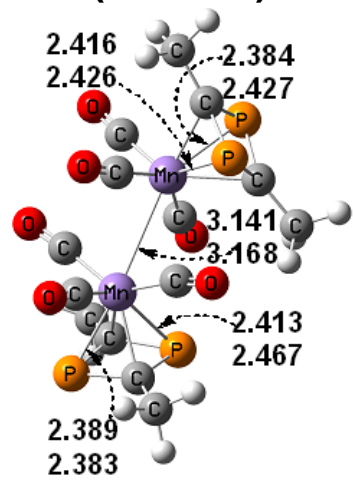

6S-5 $\left(C_{1}\right)$

(16.3/ 16.1)

(15.8/ 15.8)

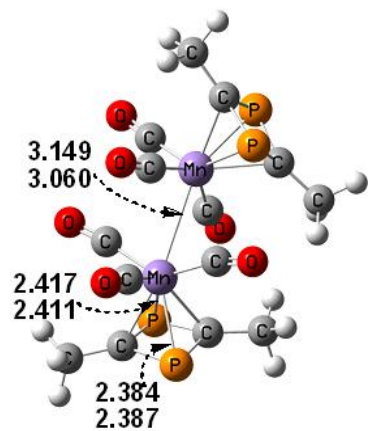

6S-3 $\left(C_{2}\right)$

(16.9/16.6)

(15.4 / 15.0)

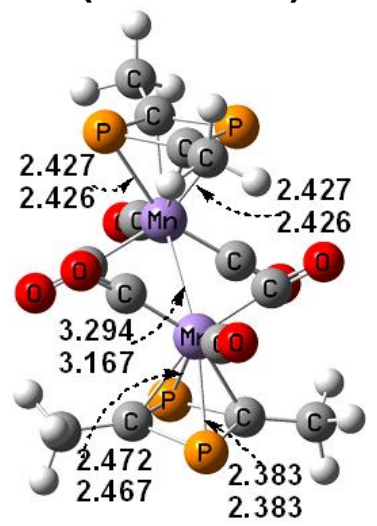

6S-6 $\left(C_{1}\right)$

(17.4/ 17.4)

(15.8/ 15.7)

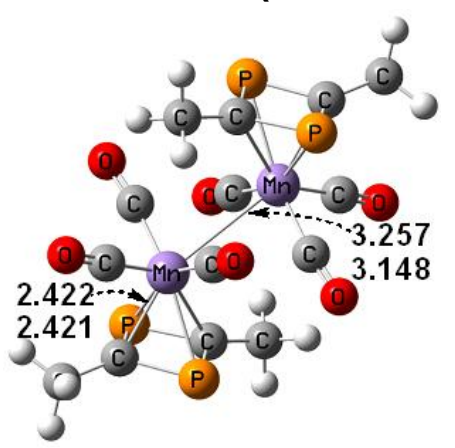

6S-8 $\left(C_{2 h}\right)$

(20.4 / 20.6)

(17.9/ 18.1)

Figure 3. The optimized $\left(\mathrm{Me}_{2} \mathrm{C}_{2} \mathrm{P}_{2}\right)_{2} \mathrm{Mn}_{2}(\mathrm{CO})_{6}$ structures. Distances $(\AA)$ and the relative energies $(\mathrm{kcal} / \mathrm{mol}$, in parentheses) without and with the ZPVE corrections are predicted by the B3LYP (upper) and the BP86 (lower) methods. 
The next lowest singlet $\left(\mathrm{Me}_{2} \mathrm{C}_{2} \mathrm{P}_{2}\right)_{2} \mathrm{Mn}_{2}(\mathrm{CO})_{5}$ structure 5S-2 lies more than $22 \mathrm{kcal} / \mathrm{mol}$ in energy above 5S-1 (Figure 4 and Table S22). Structure 5S-2 has four terminal $\mathrm{CO}$ groups symmetrically distributed between the manganese atoms as well as a bridging $\mathrm{CO}$ group. The $\eta^{4}-\mathrm{Me}_{2} \mathrm{C}_{2} \mathrm{P}_{2}$ rings in $\mathbf{5 S - 2}$ are terminal tetrahapto ligands bonded only to a single manganese atom. Interpreting the $\mathrm{Mn}=\mathrm{Mn}$ distance of $3.016 \AA$ (BP86) or $3.082 \AA$ (B3LYP) as a formal double bond gives each manganese atom the favored 18-electron configuration. Structure $\mathbf{5 S - 2}$ is closely related to an unstable $\mathrm{Cp}_{2} \mathrm{Mn}_{2}(\mathrm{CO})_{5}$ structure obtained by the flash photolysis of $\mathrm{CpMn}(\mathrm{CO})_{3}$ in hydrocarbon solution [37]. Thus the predicted $v(\mathrm{CO})$ frequencies for 5S-2 of 1742, 1915, 1945, 1960, and $1982 \mathrm{~cm}^{-1}$ (Table S26) are very close to the experimental infrared frequencies of 1777, 1907, 1934, 1955, and $1993 \mathrm{~cm}^{-1}$ of this $\mathrm{Cp}_{2} \mathrm{Mn}_{2}(\mathrm{CO})_{5}$ structure as well as the $v(\mathrm{CO})$ frequencies of 1777, 1906, 1927, 1949, and $1973 \mathrm{~cm}^{-1}$ predicted for the lowest energy $\mathrm{Cp}_{2} \mathrm{Mn}_{2}(\mathrm{CO})_{5}$ structure in a previous theoretical study [38].

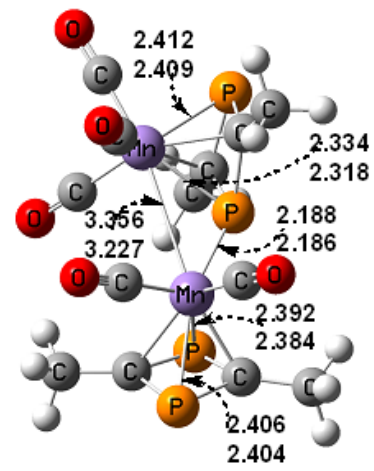

5S-1 $\left(C_{1}\right)$ $(0.0 / 0.0)$ $(0.0 / 0.0)$

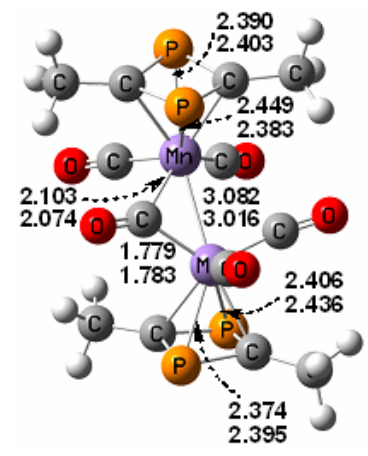

$5 \mathrm{~S}-2\left(C_{1}\right)$

$(22.3 / 22.1)$

$(22.3 / 21.7)$

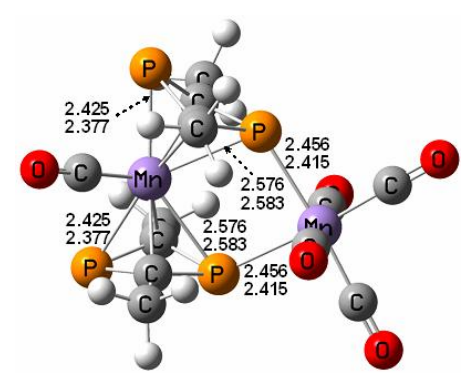

$5 \mathrm{~T}-1\left(C_{1}\right)$
$(2.2 / 1.9)$

$(12.1 / 11.6)$

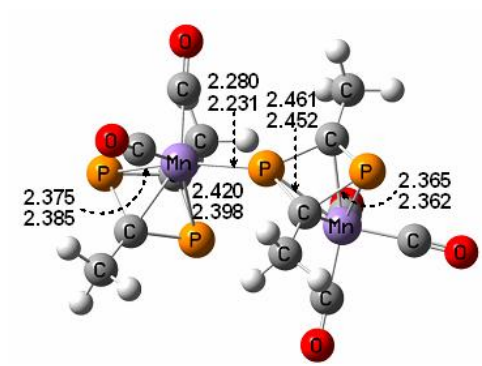

$5 \mathrm{~T}-2\left(C_{1}\right)$

$(14.3 / 12.9)$

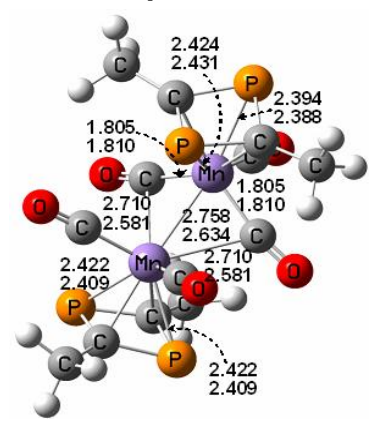

$5 \mathrm{~T}-3\left(C_{1}\right)$ $(10.8 / 9.8)$ $(20.2 / 19.0)$

Figure 4. The optimized $\left(\mathrm{Me}_{2} \mathrm{C}_{2} \mathrm{P}_{2}\right)_{2} \mathrm{Mn}_{2}(\mathrm{CO})_{5}$ structures. Distances $(\AA)$ and the relative energies ( $\mathrm{kcal} / \mathrm{mol}$, in parentheses) without and with the ZPVE corrections are predicted by the B3LYP (upper) and the BP86 (lower) methods. 
The triplet $\left(\mathrm{Me}_{2} \mathrm{C}_{2} \mathrm{P}_{2}\right)_{2} \mathrm{Mn}_{2}(\mathrm{CO})_{5}$ structure 5T-1 lies $12.1 \mathrm{kcal} / \mathrm{mol}$ (BP86) or $2.2 \mathrm{kcal} / \mathrm{mol}$ (B3LYP) in energy above 5S-1 (Figure 4 and Table S22). The two DFT methods predict different relative energies for the different spin states; the true energy difference should lie between the BP86 and B3LYP values [28]. Structure 5T-1 has a highly unsymmetrical distribution of $\mathrm{CO}$ groups with only one $\mathrm{CO}$ group bonded to one manganese atom and the remaining four $\mathrm{CO}$ groups bonded to the other manganese atom. The MnCO unit is sandwiched between both $\mathrm{Me}_{2} \mathrm{C}_{2} \mathrm{P}_{2}$ rings, each functioning as a tetrahapto ligand to that manganese atom. The resulting $\left(\mathrm{Me}_{2} \mathrm{C}_{2} \mathrm{P}_{2}\right)_{2} \mathrm{Mn}(\mathrm{CO})$ unit functions as a bidentate chelating agent to the $\mathrm{Mn}(\mathrm{CO})_{4}$ unit through one phosphorus atom in each ring. This bonding arrangement gives the $\left(\mathrm{Me}_{2} \mathrm{C}_{2} \mathrm{P}_{2}\right)_{2} \mathrm{Mn}(\mathrm{CO})$ manganese a 17-electron configuration and the $\mathrm{Mn}(\mathrm{CO})_{4}$ manganese a 19-electron configuration consistent with a binuclear triplet.

The next triplet structure 5 T-2 lies $14.3 \mathrm{kcal} / \mathrm{mol}$ (BP86) or $6.4 \mathrm{kcal} / \mathrm{mol}$ in energy above 5S-1 (B3LYP) (Figure 4 and Table S22). Structure 5T-2 has similar geometry to 5S1, but the $\mathrm{Mn}^{\cdots \cdots} \mathrm{Mn}$ distance is too long for a direct bond. Thus, each manganese atom in 5T-2 has a 17-electron configuration. Structure 5T-3, lying $20.2 \mathrm{kcal} / \mathrm{mol}$ (BP86) or 10.8 $\mathrm{kcal} / \mathrm{mol}$ (B3LYP) in energy above 5S-1, has two semibridging CO groups, three terminal $\mathrm{CO}$ groups, and two $\eta^{4}-\mathrm{Me}_{2} \mathrm{C}_{2} \mathrm{P}_{2}$ rings. The $\mathrm{Mn}=\mathrm{Mn}$ distance of $2.634 \AA$ (BP86) or 2.758 $\AA$ (B3LYP) in 5T-3 is a formal double bond thereby giving each manganese atom the favored 18-electron configuration. The triplet spin state of 5T-3 comes from the $\mathrm{Mn}=\mathrm{Mn}$ double bond being of the $\sigma+2 / 2 \pi$ type with two orthogonal $\pi$ single-electron "half-bonds" similar to those found in the stable triplet state organometallics $\left(\eta^{5}-\mathrm{R}_{5} \mathrm{C}_{5}\right)_{2} \mathrm{Fe}_{2}(\mu-\mathrm{CO})_{3}(\mathrm{R}=$ $\mathrm{H}, \mathrm{Me})[39,40,41,42]$.

3.1.3 $\left(\mathrm{Me}_{2} \mathrm{C}_{2} \mathrm{P}_{2}\right)_{2} \mathrm{Mn}_{2}(\mathrm{CO})_{4}$. For $\left(\mathrm{Me}_{2} \mathrm{C}_{2} \mathrm{P}_{2}\right)_{2} \mathrm{Mn}_{2}(\mathrm{CO})_{4}$ two singlet structures and two triplet structures were found by using the B3LYP and BP86 methods (Figure 5 and Table S23). The lowest energy $\left(\mathrm{Me}_{2} \mathrm{C}_{2} \mathrm{P}_{2}\right)_{2} \mathrm{Mn}_{2}(\mathrm{CO})_{4}$ structure 4T-1 is a triplet consisting of two $\left(\mathrm{Me}_{2} \mathrm{C}_{2} \mathrm{P}_{2}\right) \mathrm{Mn}(\mathrm{CO})_{2}$ units bridged by their two $\eta^{4}, \eta^{1}-\mathrm{Me}_{2} \mathrm{C}_{2} \mathrm{P}_{2}$ rings. Each such ring functions as a tetrahapto ligand to one of the manganese atoms and bonds to the other manganese atom through $\mathrm{P} \rightarrow \mathrm{Mn}$ dative bonds of lengths $2.255 \AA$ and $2.309 \AA$ (BP86) or $2.378 \AA$ (B3LYP). The Mn*.*Mn distance of $3.417 \AA$ (BP86) or $3.490 \AA$ (B3LYP) in 4T-1 (Table S23) is too long for a direct bond. This bonding arrangement in 4T-1 gives each manganese atom a 17-electron configuration consistent with a binuclear triplet.

The other triplet $\left(\mathrm{Me}_{2} \mathrm{C}_{2} \mathrm{P}_{2}\right)_{2} \mathrm{Mn}_{2}(\mathrm{CO})_{4}$ structure 4T-2, lying $2.2 \mathrm{kcal} / \mathrm{mol}(\mathrm{BP} 86)$ or $5.0 \mathrm{kcal} / \mathrm{mol}$ (B3LYP) in energy above 4T-1, has an even longer Mn*.Mn distance of 
$\sim 3.88 \AA$, indicating the absence of any direct metal-metal bonding (Figure 5 and Table S23). In 4T-2, an $\left(\eta^{4}, \eta^{1}-\mathrm{Me}_{2} \mathrm{C}_{2} \mathrm{P}_{2}\right)_{2} \mathrm{Mn}(\mathrm{CO})$ moiety functions as a bidentate chelating ligand to an $\mathrm{Mn}(\mathrm{CO})_{3}$ moiety through two $\mathrm{P} \rightarrow \mathrm{Mn}$ dative bonds of lengths $2.278 \AA$ and $2.425 \AA$ (BP86) or $2.317 \AA$ and $2.415 \AA$ (B3LYP) (Figure 3). This gives each manganese atom in 4T-2 a 17-electron configuration, consistent with a binuclear triplet. Structure 4T-2 can be derived from 5T-1 by removal of a $\mathrm{CO}$ group from the $\mathrm{Mn}(\mathrm{CO})_{4}$ unit.

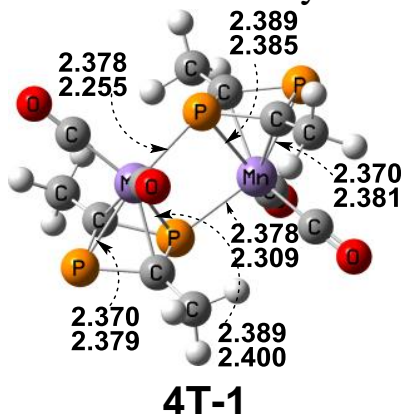

$(0.0 / 0.0)$

$(0.0 / 0.0)$

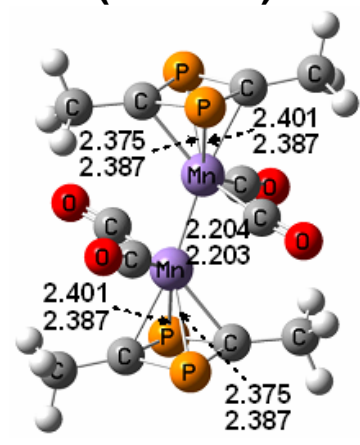

4S-1

$(17.4 / 18.6)$

(1.7 / 2.8)

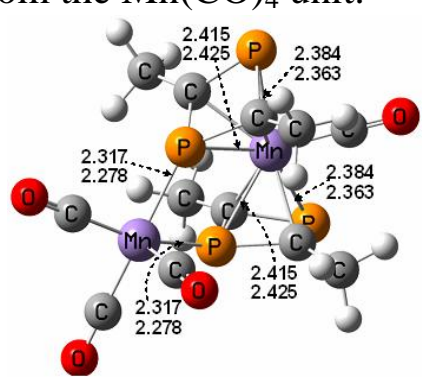

4T-2

$(5.0 / 5.9)$

$(2.3 / 3.2)$

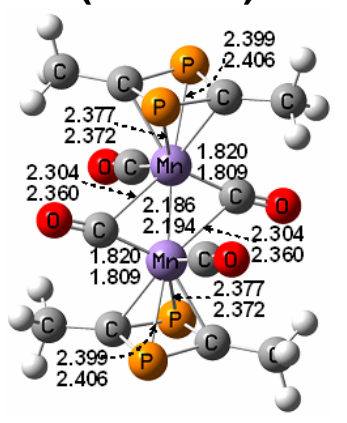

4S-2

$(18.9 / 20.0)$

(3.6 / 4.5)

Figure 5. The optimized $\left(\mathrm{Me}_{2} \mathrm{C}_{2} \mathrm{P}_{2}\right)_{2} \mathrm{Mn}_{2}(\mathrm{CO})_{4}$ structures. Distances $(\AA)$ and the relative energies $(\mathrm{kcal} / \mathrm{mol}$, in parentheses) without and with the ZPVE corrections are predicted by the B3LYP (upper) and the BP86 (lower) methods.

The two singlet $\left(\mathrm{Me}_{2} \mathrm{C}_{2} \mathrm{P}_{2}\right)_{2} \mathrm{Mn}_{2}(\mathrm{CO})_{4}$ structures have terminal $\eta^{4}-\mathrm{Me}_{2} \mathrm{C}_{2} \mathrm{P}_{2}$ rings and very short $\mathrm{Mn} \equiv \mathrm{Mn}$ distances of $\sim 2.2 \AA$ consistent with the formal triple bonds required to give each manganese atom the favored 18-electron configuration (Figure 5). Structure 4S-1, lying $1.7 \mathrm{kcal} / \mathrm{mol}$ (BP86) or $17.4 \mathrm{kcal} / \mathrm{mol}$ (B3LYP) in energy above 4T-1, has four essentially terminal CO groups. Again, the two DFT methods predict different relative energies for the different spin states; the true energy difference should lie between the BP86 and B3LYP values [28]. Structure 4S-2, lying $3.6 \mathrm{kcal} / \mathrm{mol}$ (BP86) or $18.9 \mathrm{kcal} / \mathrm{mol}$ (B3LYP) in energy above 4T-1, has two terminal CO groups and two semibridging CO 
groups. These singlet $\left(\mathrm{Me}_{2} \mathrm{C}_{2} \mathrm{P}_{2}\right)_{2} \mathrm{Mn}_{2}(\mathrm{CO})_{4}$ structures are closely related to the experimentally known $\left(\eta^{5}-\mathrm{R}_{5} \mathrm{C}_{5}\right)_{2} \mathrm{Cr}_{2}(\mathrm{CO})_{4}$ structures $(\mathrm{R}=\mathrm{H}[43]$, Me [44,45]), which likewise have short $\mathrm{Cr} \equiv \mathrm{Cr}$ distances of $\sim 2.24 \AA$, as determined by X-ray crystallography.

3.1.4 $\left(\mathrm{Me}_{2} \mathrm{C}_{2} \mathrm{P}_{2}\right)_{2} \mathrm{Mn}_{2}(\mathrm{CO})_{3}$. For $\left(\mathrm{Me}_{2} \mathrm{C}_{2} \mathrm{P}_{2}\right)_{2} \mathrm{Mn}_{2}(\mathrm{CO})_{3}$ two triplet and two singlet structures were found by using the B3LYP and BP86 methods (Figure 6 and Table S24). The triplet $\left(\mathrm{Me}_{2} \mathrm{C}_{2} \mathrm{P}_{2}\right)_{2} \mathrm{Mn}_{2}(\mathrm{CO})_{3}$ structures have lower energies than the isomeric singlet structures. Thus the global minimum $\left(\mathrm{Me}_{2} \mathrm{C}_{2} \mathrm{P}_{2}\right)_{2} \mathrm{Mn}_{2}(\mathrm{CO})_{3}$ structure is 3T-1 with the other triplet structure 3T-2 lying $8.1 \mathrm{kcal} / \mathrm{mol}$ (BP86) or $14.8 \mathrm{kcal} / \mathrm{mol}$ (B3LYP) in energy above 3T-1. The two singlet $\left(\mathrm{Me}_{2} \mathrm{C}_{2} \mathrm{P}_{2}\right)_{2} \mathrm{Mn}_{2}(\mathrm{CO})_{3}$ structures 3S-1 and 3S-2 lie 15.0 and $17.5 \mathrm{kcal} / \mathrm{mol}$ (BP86) or 34.8 and $35.2 \mathrm{kcal} / \mathrm{mol}$ (B3LYP), respectively, in energy above 3T-1. In all four $\left(\mathrm{Me}_{2} \mathrm{C}_{2} \mathrm{P}_{2}\right)_{2} \mathrm{Mn}_{2}(\mathrm{CO})_{3}$ structures the $\eta^{4}-\mathrm{Me}_{2} \mathrm{C}_{2} \mathrm{P}_{2}$ rings are terminal tetrahapto ligands, bonded to a single manganese atom. The triplet structure 3T-1 has three semibridging CO groups with the three shorter Mn-C distances of $\sim 1.8 \AA$ to the same manganese atom and three longer Mn-C distances of $\sim 2.4 \AA$ to the other manganese atom. The singlet structure 3S-1 has three semibridging $\mathrm{CO}$ groups with two shorter $\mathrm{Mn}-\mathrm{C}$ distances of $\sim 1.8$ $\AA$ to one manganese atom and a third shorter $\sim 1.8 \AA$ distance to the other manganese atom. The triplet $\left(\mathrm{Me}_{2} \mathrm{C}_{2} \mathrm{P}_{2}\right)_{2} \mathrm{Mn}_{2}(\mathrm{CO})_{3}$ structure 3T-2 has one symmetrical bridging $\mathrm{CO}$ group and two semibridging $\mathrm{CO}$ groups, whereas the singlet structure 3S-2 has two bridging $\mathrm{CO}$ groups and one semibridging $\mathrm{CO}$ group. The $\mathrm{Mn}-\mathrm{Mn}$ distances for all four $\left(\mathrm{Me}_{2} \mathrm{C}_{2} \mathrm{P}_{2}\right)_{2} \mathrm{Mn}_{2}(\mathrm{CO})_{3}$ structures are relatively short, ranging from $\sim 2.22$ to $\sim 2.34 \AA$ consistent with formal triple or quadruple bonds.

\subsection{Thermochemistry}

Table 1 shows the dissociation energies for the reactions $\left(\mathrm{Me}_{2} \mathrm{C}_{2} \mathrm{P}_{2}\right)_{2} \mathrm{Mn}_{2}(\mathrm{CO})_{n} \rightarrow$ $\left(\mathrm{Me}_{2} \mathrm{C}_{2} \mathrm{P}_{2}\right)_{2} \mathrm{Mn}_{2}(\mathrm{CO})_{n-1}+\mathrm{CO}(n=6,5,4)$ considering the lowest energy structures. The $\mathrm{CO}$ dissociation energies $(\Delta \mathrm{E})$ are all sufficiently endothermic (by 14 to $44 \mathrm{kcal} / \mathrm{mol}$ ) to suggest viability towards CO loss. For comparison, the experimental dissociation energies for the well-known simple metal carbonyls $\mathrm{Ni}(\mathrm{CO})_{4}, \mathrm{Fe}(\mathrm{CO})_{5}$, and $\mathrm{Cr}(\mathrm{CO})_{6}$ are 27, 41, and $37 \mathrm{kcal} / \mathrm{mol}$, respectively [46]. The corresponding free energies $(\Delta \mathrm{G})$ are somewhat smaller (by 11 to $13 \mathrm{kcal} / \mathrm{mol}$ ), since the entropy values usually increase for dissociation processes. However, all of the free energies in Table 1 remain positive, still indicating that these complexes are viable towards $\mathrm{CO}$ loss. The monotonic increase of the $\mathrm{CO}$ dissociation energies of the $\left(\mathrm{Me}_{2} \mathrm{C}_{2} \mathrm{P}_{2}\right)_{2} \mathrm{Mn}_{2}(\mathrm{CO})_{n}$ derivatives with decreasing numbers of $\mathrm{CO}$ groups is consistent with the endothermic nature of the disproportionation processes 
$2\left(\mathrm{Me}_{2} \mathrm{C}_{2} \mathrm{P}_{2}\right)_{2} \mathrm{Mn}_{2}(\mathrm{CO})_{n} \rightarrow\left(\mathrm{Me}_{2} \mathrm{C}_{2} \mathrm{P}_{2}\right)_{2} \mathrm{Mn}_{2}(\mathrm{CO})_{n+1}+\left(\mathrm{Me}_{2} \mathrm{C}_{2} \mathrm{P}_{2}\right)_{2} \mathrm{Mn}_{2}(\mathrm{CO})_{n-1}$ listed in Table 2.

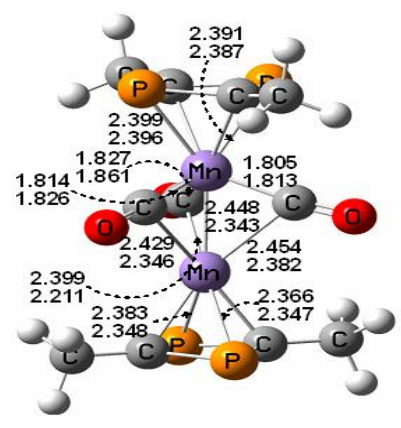

3T-1

(0.0 / 0.0)

$(0.0 / 0.0)$

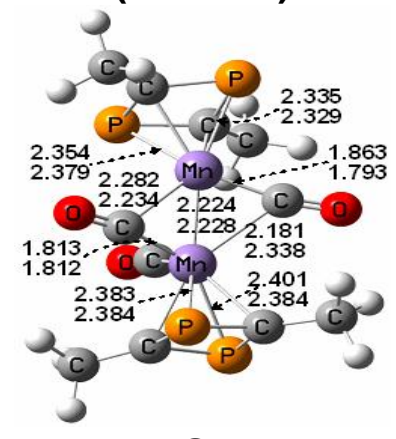

3S-1

$(15.0 / 15.0)$

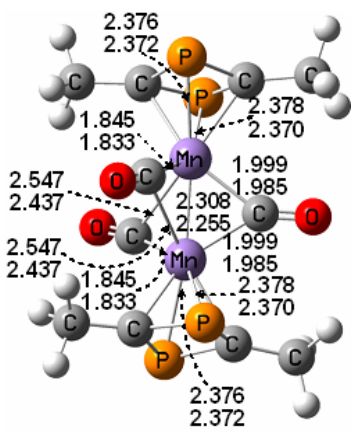

3T-2

$(14.8 / 14.4)$

(8.1 / 7.9)

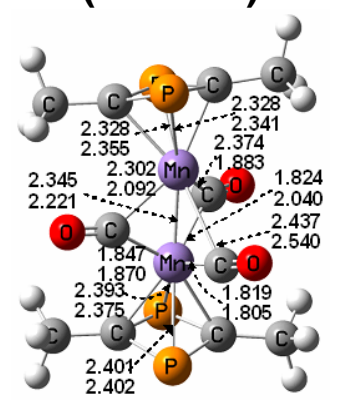

3S-2

$(35.2$ / 35.4)

$(17.5 / 17.4)$

Figure 6. The optimized $\left(\mathrm{Me}_{2} \mathrm{C}_{2} \mathrm{P}_{2}\right)_{2} \mathrm{Mn}_{2}(\mathrm{CO})_{3}$ structures. Distances $(\AA)$ ) and the relative energies ( $\mathrm{kcal} / \mathrm{mol}$, in parentheses) without and with the ZPVE corrections are predicted by the B3LYP (upper) and the BP86 (lower) methods.

Table 1. Dissociation energies $(\Delta \mathrm{E}, \mathrm{kcal} / \mathrm{mol})$ and the Gibbs free energies at $298 \mathrm{~K}(\Delta \mathrm{G}$, $\mathrm{kcal} / \mathrm{mol}$ ) for the successive removal of carbonyl groups from the lowest-energy $\left(\mathrm{Me}_{2} \mathrm{C}_{2} \mathrm{P}_{2}\right)_{2} \mathrm{Mn}_{2}(\mathrm{CO})_{n}$ derivatives.

\begin{tabular}{ccccc}
\hline \hline & \multicolumn{2}{c}{ B3LYP } & \multicolumn{2}{c}{ BP86 } \\
\hline$(\mathbf{6 S - 1}) \rightarrow(\mathbf{5 S}-\mathbf{1})+\mathrm{CO}$ & $\Delta \mathrm{E}$ & $\Delta \mathrm{G}$ & $\Delta \mathrm{E}$ & $\Delta \mathrm{G}$ \\
\hline$(\mathbf{5 S}-\mathbf{1}) \rightarrow(\mathbf{4 T}-\mathbf{1})+\mathrm{CO}$ & 14.8 & 3.2 & 20.4 & 9.9 \\
$(\mathbf{4 T}-\mathbf{1}) \rightarrow(\mathbf{3 T}-\mathbf{1})+\mathrm{CO}$ & 24.8 & 9.8 & 38.6 & 22.7 \\
& 31.6 & 18.2 & 44.5 & 32.3 \\
\hline
\end{tabular}


Table 2. Disproportionation energies $(\Delta \mathrm{E}, \mathrm{kcal} / \mathrm{mol})$ and the Gibbs free energies at $298 \mathrm{~K}$ $(\Delta \mathrm{G}, \quad \mathrm{kcal} / \mathrm{mol})$ for the $2\left(\mathrm{Me}_{2} \mathrm{C}_{2} \mathrm{P}_{2}\right)_{2} \mathrm{Mn}_{2}(\mathrm{CO})_{n} \rightarrow\left(\mathrm{Me}_{2} \mathrm{C}_{2} \mathrm{P}_{2}\right)_{2} \mathrm{Mn}_{2}(\mathrm{CO})_{n+1}+$ $\left(\mathrm{Me}_{2} \mathrm{C}_{2} \mathrm{P}_{2}\right)_{2} \mathrm{Mn}_{2}(\mathrm{CO})_{n-1}$ reactions $(n=5,4)$.

\begin{tabular}{lcccc}
\hline & \multicolumn{2}{c}{ B3LYP } & \multicolumn{2}{c}{ BP86 } \\
\hline & $\Delta \mathrm{E}$ & $\Delta \mathrm{G}$ & $\Delta \mathrm{E}$ & $\Delta \mathrm{G}$ \\
\hline $2(\mathbf{5 S}-1) \rightarrow(\mathbf{6 S}-1)+(\mathbf{4 T}-1)$ & 10.0 & 6.6 & 18.2 & 12.8 \\
$2(\mathbf{4 T}-1) \rightarrow(\mathbf{5 S}-1)+($ 3T-1 $)$ & 6.7 & 8.4 & 5.9 & 9.5 \\
\hline
\end{tabular}
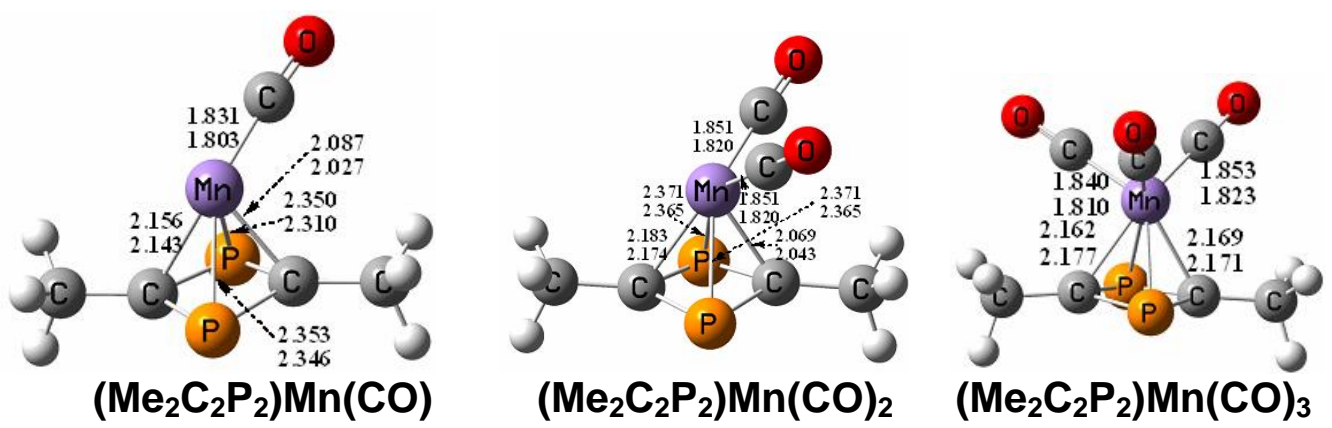

Figure 7. Optimized geometries for the mononuclear structures $\left(\mathrm{Me}_{2} \mathrm{C}_{2} \mathrm{P}_{2}\right)_{2} \mathrm{Mn}_{2}(\mathrm{CO})_{m}(m=$ $3,2,1)$, which are the dissociation products in Table 3 .

Also of interest is the dissociation of the $\left(\mathrm{Me}_{2} \mathrm{C}_{2} \mathrm{P}_{2}\right)_{2} \mathrm{Mn}_{2}(\mathrm{CO})_{n}$ derivatives into mononuclear $\left(\mathrm{Me}_{2} \mathrm{C}_{2} \mathrm{P}_{2}\right) \mathrm{Mn}(\mathrm{CO})_{m}$ fragments. In order to obtain such energetic data, the structures of the mononuclear $\left(\mathrm{Me}_{2} \mathrm{C}_{2} \mathrm{P}_{2}\right) \mathrm{Mn}(\mathrm{CO})_{m}$ were optimized by the same DFT methods as used to study the binuclear derivatives (Figure 7 and Table S29). Using this information the dissociation energies of the binuclear metal-carbonyl derivatives into mononuclear fragments were obtained (Table 3$)$. The predicted dissociation energies $(\triangle \mathrm{E}$, in Table 3) range from 9 to $55 \mathrm{kcal} / \mathrm{mol}$ (B3LYP) or 22 to $66 \mathrm{kcal} / \mathrm{mol}$ (BP86). Thus all of the dissociation energies are strongly positive, indicating that the lowest-energy $\left(\mathrm{Me}_{2} \mathrm{C}_{2} \mathrm{P}_{2}\right)_{2} \mathrm{Mn}_{2}(\mathrm{CO})_{n}$ structures are viable towards dissociation into mononuclear fragments. Similar to those in Table 1 , the free energies $(\Delta G$ in Table 3$)$ are 15 to $18 \mathrm{kcal} / \mathrm{mol}$ lower than the enthalpies ( $\triangle \mathrm{E}$ in Table 3 ). All of the free energies except for 6S-1, are positive, indicating these complexes are stable for the CO loss reactions. For 6S1 , the $\Delta \mathrm{G}$ value is $-8 \mathrm{kcal} / \mathrm{mol}$ (B3LYP) or $+6 \mathrm{kcal} / \mathrm{mol}$ (BP86). The true value should lie between these values [28] suggesting $\mathbf{6 S - 1}$ to be thermoneutral for dissociation into two mononuclear $\left(\mathrm{Me}_{2} \mathrm{C}_{2} \mathrm{P}_{2}\right) \mathrm{Mn}(\mathrm{CO})_{3}$ fragments. Table 3 also shows that the dissociation energies of $\left(\mathrm{Me}_{2} \mathrm{C}_{2} \mathrm{P}_{2}\right)_{2} \mathrm{Mn}_{2}(\mathrm{CO})_{n}$ into mononuclear fragments increase monotonically with decreasing $n$. 
Table 3. Energies ( $\Delta \mathrm{E}, \mathrm{kcal} / \mathrm{mol})$ and Gibbs free energies $(\Delta \mathrm{G}, \mathrm{kcal} / \mathrm{mol}), 298 \mathrm{~K})$ for the dissociation of the binuclear $\left(\mathrm{Me}_{2} \mathrm{C}_{2} \mathrm{P}_{2}\right)_{2} \mathrm{Mn}_{2}(\mathrm{CO})_{n}(n=6,5,4,3)$ derivatives into mononuclear fragments.

\begin{tabular}{ccccc}
\hline \hline & \multicolumn{2}{c}{ B3LYP } & \multicolumn{2}{c}{ BP86 } \\
\hline$($ 6S-1 $) \rightarrow 2\left(\mathrm{Me}_{2} \mathrm{C}_{2} \mathrm{P}_{2}\right) \mathrm{Mn}(\mathrm{CO})_{3}$ & $\Delta \mathrm{E}$ & $\Delta \mathrm{G}$ & $\Delta \mathrm{E}$ & $\Delta \mathrm{G}$ \\
\hline$(\mathbf{5 S - 1}) \rightarrow\left(\mathrm{Me}_{2} \mathrm{C}_{2} \mathrm{P}_{2}\right) \mathrm{Mn}(\mathrm{CO})_{3}+\left(\mathrm{Me}_{2} \mathrm{C}_{2} \mathrm{P}_{2}\right) \mathrm{Mn}(\mathrm{CO})_{2}$ & 9.0 & -8.0 & 22.5 & 6.4 \\
$(\mathbf{4 T - 1}) \rightarrow 2\left(\mathrm{Me}_{2} \mathrm{C}_{2} \mathrm{P}_{2}\right) \mathrm{Mn}(\mathrm{CO})_{2}$ & 32.4 & 14.1 & 49.9 & 31.7 \\
$(\mathbf{3 T - 1}) \rightarrow\left(\mathrm{Me}_{2} \mathrm{C}_{2} \mathrm{P}_{2}\right) \mathrm{Mn}(\mathrm{CO})_{2}+\left(\mathrm{Me}_{2} \mathrm{C}_{2} \mathrm{P}_{2}\right) \mathrm{Mn}(\mathrm{CO})$ & 55.8 & 29.5 & 59.2 & 44.2 \\
\end{tabular}

\subsection{Natural Bond Orbital (NBO) analysis}

Table 4 lists the natural atomic charges for the manganese atoms and the Wiberg Bond Indices (WBI) for the Mn-Mn bonds in the lowest-energy singlet structures, carried out with the NBO 3.1 version [47] attached to Gaussian03 program [48]. Triplet structures are not included since our experience suggests that WBI values are not as reliable for structures with unpaired electrons. The formal Mn-Mn bond orders along with the Mn-Mn distances are also listed for comparison.

Table 4. Natural atomic charges on $\mathrm{Mn}$ atoms and Wiberg bond indices for the $\mathrm{Mn}-\mathrm{Mn}$ bond in the lowest-lying $\left(\mathrm{Me}_{2} \mathrm{C}_{2} \mathrm{P}_{2}\right) \mathrm{Mn}_{2}(\mathrm{CO})_{n}$ structures by the B3LYP and BP86 methods.

\begin{tabular}{ccccc}
\hline & $\begin{array}{c}\text { Natural Charges } \\
\text { on the Mn/Mn Atoms }\end{array}$ & $\begin{array}{c}\text { Mn-Mn Wiberg } \\
\text { Bond Index }\end{array}$ & $\begin{array}{c}\text { Mn-Mn Distance } \\
(\AA)\end{array}$ & $\begin{array}{c}\text { Formal } \\
\text { Bond Order }\end{array}$ \\
\hline B3LYP & & & & \\
6S-1 & $-0.85 /-0.74$ & 0.02 & 4.603 & 0 \\
5S-1 & $-0.65 /-0.72$ & 0.18 & 3.356 & 1 \\
BP86 & & & & \\
6S-1 & $-0.87 /-0.77$ & 0.03 & 4.544 & 0 \\
5S-1 & $-0.73 /-0.73$ & 0.19 & 3.227 & 1 \\
\hline
\end{tabular}

All of the atomic charges for the manganese atoms are negative because the manganese atoms accept electrons from the $\mathrm{CO}$ and the phosphorus lone pairs, and the $\pi$ back-bonding from the manganese atoms to the antibonding orbitals of the CO groups is not sufficient to compensate for the $\sigma$ forward bonding. The charges depend on the number of the ligands attached on the manganese atoms. For example, for the manganese atoms bearing three $\mathrm{CO}$ groups or two $\mathrm{CO}$ groups plus a phosphorus lone pair (in $\mathbf{6 S - 1}$ and $\mathbf{5 S - 1}$ ), the atomic charges range from -0.65 to -0.77 . The negative charge of -0.85 (or 0.87 ) in $\mathbf{6 S - 1}$ is for the manganese atom bearing three $\mathrm{CO}$ groups plus a phosphorus lone pair. 
Previous studies on the Wiberg Bond Indices (WBIs) of metal carbonyls such as $\mathrm{Fe}_{2}(\mathrm{CO})_{9}$ and $\mathrm{Fe}_{3}(\mathrm{CO})_{12}$ show that the WBI values are relatively low, often only 0.2 to 0.3 for formal metal-metal single bonds [49]. This is also true for the Mn-Mn interactions in the singlet structures discussed in the present paper. Thus the WBI value for the Mn-Mn single bond in $\mathbf{5 S - 1}$ is only $\sim 0.2$. This contrasts with the WBI value of 0.03 for the non-

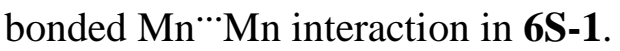

\section{Discussion}

Previous theoretical studies on the binuclear 1,3-diphosphacyclobutadiene iron carbonyls $\left(\mathrm{Me}_{2} \mathrm{C}_{2} \mathrm{P}_{2}\right)_{2} \mathrm{Fe}_{2}(\mathrm{CO})_{n}$ [12] and the phospholyl manganese carbonyls $\left(\mathrm{C}_{4} \mathrm{H}_{4} \mathrm{P}\right)_{2} \mathrm{Mn}_{2}(\mathrm{CO})_{n}$ [14] indicate a strong energetic preference for structures with bridging rather than terminal phosphorus heterocycle rings except for $\left(\mathrm{Me}_{2} \mathrm{C}_{2} \mathrm{P}_{2}\right)_{2} \mathrm{Fe}_{2}(\mathrm{CO})_{3}$ and $\left(\mathrm{C}_{4} \mathrm{H}_{4} \mathrm{P}\right)_{2} \mathrm{Mn}_{2}(\mathrm{CO})_{3}$ for which structures with terminal phosphorus heterocycle rings and formal $\mathrm{M} \equiv \mathrm{M}$ triple bonds are energetically preferred. The bridging phosphorus heterocycle rings typically use all of their atoms to bond to one metal atom and the phosphorus lone pair to bond to a second metal atom. Such a bridging 1,3-diphosphacyclobutadiene is thus a six-electron donor to a pair of metal atoms. Similarly a bridging phospholyl ligand of this type is a seven-electron donor to a pair of metal atoms. A similar trend is evident in the 1,3-diphosphacyclobutadiene manganese carbonyls $\left(\mathrm{Me}_{2} \mathrm{C}_{2} \mathrm{P}_{2}\right)_{2} \mathrm{Mn}_{2}(\mathrm{CO})_{n}$ discussed in this paper.

Consider first the hexacarbonyl system $\left(\mathrm{Me}_{2} \mathrm{C}_{2} \mathrm{P}_{2}\right)_{2} \mathrm{Mn}_{2}(\mathrm{CO})_{6}$ (Figure 3). The lowest energy structure $\mathbf{6 S - 1}$ has a $\left(\eta^{4}, \eta^{1}-\mathrm{Me}_{2} \mathrm{C}_{2} \mathrm{P}_{2}\right) \mathrm{Mn}(\mathrm{CO})_{3}$ unit coordinated to a second $\left(\eta^{4}-\mathrm{Me}_{2} \mathrm{C}_{2} \mathrm{P}_{2}\right) \mathrm{Mn}(\mathrm{CO})_{3}$ unit through a $\mathrm{P} \rightarrow \mathrm{Mn}$ dative bond. The next lowest energy structure 6S-2, at only $\sim 4 \mathrm{kcal} / \mathrm{mol}$ in energy above 6S-1, is similar to $6 \mathrm{~S}-1$ but has an unsymmetrical distribution of CO groups on the manganese atoms. Thus in $6 \mathbf{S - 2}$ an $\left(\eta^{4}, \eta^{1}\right.$ $\left.\mathrm{Me}_{2} \mathrm{C}_{2} \mathrm{P}_{2}\right) \mathrm{Mn}(\mathrm{CO})_{4}$ tetracarbonyl unit is coordinated to a $\left(\eta^{4}-\mathrm{Me}_{2} \mathrm{C}_{2} \mathrm{P}_{2}\right) \mathrm{Mn}(\mathrm{CO})_{2}$ dicarbonyl unit through a $\mathrm{P} \rightarrow \mathrm{M}$ dative bond that is $\sim 0.4 \AA$ shorter than that in $\mathbf{6 S - 1}$.

The lowest energy $\left(\mathrm{Me}_{2} \mathrm{C}_{2} \mathrm{P}_{2}\right)_{2} \mathrm{Mn}_{2}(\mathrm{CO})_{6}$ structure with exclusively terminal $\eta^{4}-\mathrm{Me}_{2} \mathrm{C}_{2} \mathrm{P}_{2}$ rings $6 \mathrm{~S}-3$ lies $\sim 15 \mathrm{kcal} / \mathrm{mol}$ in energy above $\mathbf{6 S - 1}$. Structure $\mathbf{6 S - 3}$ is the first of a series of six closely related stereoisomers lying between 15 and $18 \mathrm{kcal} / \mathrm{mol}$ in energy above 6S-1, all with terminal $\eta^{4}-\mathrm{Me}_{2} \mathrm{C}_{2} \mathrm{P}_{2}$ rings and thus no $\mathrm{P} \rightarrow \mathrm{Mn}$ dative bonds (Figure 3). The predicted $\mathrm{Mn}-\mathrm{Mn}$ distances ranging from $\sim 3.0$ to $3.4 \AA$ can be considered to be long formal single bonds. These $\mathrm{Mn}-\mathrm{Mn}$ distances can be compared with the predicted $\mathrm{Mn}-\mathrm{Mn}$ single bond distance of $\sim 3.04 \AA$ in the cyclobutadiene complex $\left(\eta^{4}-\mathrm{C}_{4} \mathrm{H}_{4}\right)_{2} \mathrm{Mn}_{2}(\mathrm{CO})_{6}$ [16].

The lowest energy $\left(\mathrm{Me}_{2} \mathrm{C}_{2} \mathrm{P}_{2}\right)_{2} \mathrm{Mn}_{2}(\mathrm{CO})_{5}$ structure 5S-1 for the pentacarbonyl $\left(\mathrm{Me}_{2} \mathrm{C}_{2} \mathrm{P}_{2}\right)_{2} \mathrm{Mn}_{2}(\mathrm{CO})_{5}$ has an $\left(\eta^{4}, \eta^{1}-\mathrm{Me}_{2} \mathrm{C}_{2} \mathrm{P}_{2}\right) \mathrm{Mn}(\mathrm{CO})_{3}$ unit coordinated to an 
$\left(\eta^{4}-\mathrm{Me}_{2} \mathrm{C}_{2} \mathrm{P}_{2}\right) \mathrm{Mn}(\mathrm{CO})_{2}$ unit through a $\mathrm{P} \rightarrow \mathrm{Mn}$ dative bond (Figure 4). In this case an MnMn single bond is required to give each manganese atom the favored 18-electron configuration. This $\mathrm{Mn}-\mathrm{Mn}$ single bond is predicted to be relatively long at $3.356 \AA$ (B3LYP) or $3.227 \AA$ (BP86).

Structure 5S-1 for $\left(\mathrm{Me}_{2} \mathrm{C}_{2} \mathrm{P}_{2}\right)_{2} \mathrm{Mn}_{2}(\mathrm{CO})_{5}$ is a very favorable structure since it lies $\sim 22 \mathrm{kcal} / \mathrm{mol}$ in energy below the next lowest energy structure. This structure appears to be a reasonable synthetic objective. The next lowest energy $\left(\mathrm{Me}_{2} \mathrm{C}_{2} \mathrm{P}_{2}\right)_{2} \mathrm{Mn}_{2}(\mathrm{CO})_{5}$ structure 5S-2 with a single $\mathrm{CO}$ bridge is the lowest energy structure with exclusively terminal $\eta^{4}-\mathrm{Me}_{2} \mathrm{C}_{2} \mathrm{P}_{2}$ rings (Figure 4). The predicted $\mathrm{Mn}-\mathrm{Mn}$ distance of $\sim 3.0 \AA$ in $\mathbf{5 S - 2}$ is very similar to the predicted $\sim 3.06 \AA \mathrm{Mn}-\mathrm{Mn}$ distance in the corresponding cyclobutadiene manganese carbonyl derivative [16].

The tetracarbonyl system $\left(\mathrm{Me}_{2} \mathrm{C}_{2} \mathrm{P}_{2}\right)_{2} \mathrm{Mn}_{2}(\mathrm{CO})_{4}$ has structures with terminal and with bridging $\mathrm{Me}_{2} \mathrm{C}_{2} \mathrm{P}_{2}$ rings of comparable energies (Figure 5). The singlet structures 4S-1 with exclusively terminal $\mathrm{CO}$ groups and 4S-2 with two bridging $\mathrm{CO}$ groups and two terminal $\mathrm{CO}$ groups both have predicted very short $\mathrm{Mn} \equiv \mathrm{Mn}$ bond lengths of $\sim 2.2 \AA$, interpreted as the formal triple bonds required to give each manganese atom the favored 18-electron configuration. Of comparable energies are the triplet $\left(\mathrm{Me}_{2} \mathrm{C}_{2} \mathrm{P}_{2}\right)_{2} \mathrm{Mn}_{2}(\mathrm{CO})_{4}$ structures 4T-1 and 4T-2 having two $\left(\eta^{4}, \eta^{1}-\mathrm{Me}_{2} \mathrm{C}_{2} \mathrm{P}_{2}\right) \mathrm{Mn}(\mathrm{CO})_{2}$ units joined by $\mathrm{P} \rightarrow \mathrm{Mn}$ dative bonds in each direction. The $\mathrm{Mn}^{\cdots}{ }^{\cdots} \mathrm{Mn}$ distances in 4T-1 and 4T-2 are long enough to be considered non-bonding so that each manganese atom in these structures has a 17-electron configuration corresponding to a binuclear triplet.

The singlet and triplet low-energy structures for the highly unsaturated tricarbonyl system $\left(\mathrm{Me}_{2} \mathrm{C}_{2} \mathrm{P}_{2}\right)_{2} \mathrm{Mn}_{2}(\mathrm{CO})_{3}$ all have terminal $\eta^{4}-\mathrm{Me}_{2} \mathrm{C}_{2} \mathrm{P}_{2}$ rings and three bridging $\mathrm{CO}$ groups and differ mainly in the orientation of the $\eta^{4}-\mathrm{Me}_{2} \mathrm{C}_{2} \mathrm{P}_{2}$ rings (Figure 6). The short Mn-Mn distances of $\sim 2.2$ to $2.3 \AA$ are consistent with the multiple bonding required to give the manganese atoms reasonable electronic configurations. The loss of the strong $\pi$ acceptor $\mathrm{CO}$ ligands in going from $\left(\mathrm{Me}_{2} \mathrm{C}_{2} \mathrm{P}_{2}\right)_{2} \mathrm{Mn}_{2}(\mathrm{CO})_{6}$ to $\left(\mathrm{Me}_{2} \mathrm{C}_{2} \mathrm{P}_{2}\right)_{2} \mathrm{Mn}_{2}(\mathrm{CO})_{3}$ increases the negative charge on the manganese atoms so that they are less receptive to phosphorus coordination through $\mathrm{P} \rightarrow \mathrm{Mn}$ dative bonds. 


\section{Summary}

The lowest energy $\left(\mathrm{Me}_{2} \mathrm{C}_{2} \mathrm{P}_{2}\right)_{2} \mathrm{Mn}_{2}(\mathrm{CO})_{n} \quad(n=6$, 5) structures have two mononuclear $\left(\mathrm{Me}_{2} \mathrm{C}_{2} \mathrm{P}_{2}\right)_{2} \mathrm{Mn}_{2}(\mathrm{CO})_{m}$ fragments linked by $\mathrm{P} \rightarrow \mathrm{M}$ dative bonds. The lowest energy isomers with terminal $\eta^{4}-\mathrm{Me}_{2} \mathrm{C}_{2} \mathrm{P}_{2}$ rings and $\mathrm{Mn}-\mathrm{Mn}$ bonds lie $\sim 15$ and $\sim 22 \mathrm{kcal} / \mathrm{mol}$ above these global minima for $\left(\mathrm{Me}_{2} \mathrm{C}_{2} \mathrm{P}_{2}\right)_{2} \mathrm{Mn}_{2}(\mathrm{CO})_{6}$ and $\left(\mathrm{Me}_{2} \mathrm{C}_{2} \mathrm{P}_{2}\right) \mathrm{Mn}_{2}(\mathrm{CO})_{5}$, respectively. For the $\left(\mathrm{Me}_{2} \mathrm{C}_{2} \mathrm{P}_{2}\right)_{2} \mathrm{Mn}_{2}(\mathrm{CO})_{4}$ system, singlet structures with terminal $\eta^{4}-\mathrm{Me}_{2} \mathrm{C}_{2} \mathrm{P}_{2}$ rings and formal $\mathrm{Mn} \equiv \mathrm{Mn}$ triple bonds are of comparable energies to triplet structures consisting of $\left(\mathrm{Me}_{2} \mathrm{C}_{2} \mathrm{P}_{2}\right)_{2} \mathrm{Mn}_{2}(\mathrm{CO})_{m}$ fragments linked by two $\mathrm{P} \rightarrow \mathrm{M}$ dative bonds. All of the low-energy $\left(\mathrm{Me}_{2} \mathrm{C}_{2} \mathrm{P}_{2}\right)_{2} \mathrm{Mn}_{2}(\mathrm{CO})_{3}$ structures have terminal $\eta^{4}-\mathrm{Me}_{2} \mathrm{C}_{2} \mathrm{P}_{2}$ rings and three bridging $\mathrm{CO}$ groups with short Mn-Mn distances indicative of formal multiple bonds.

Acknowledgment. This research was supported by Funds for Sichuan Distinguished Scientists (Grant No. 2015JQ0042), Funds for the Youth Innovation Team of the Education Department of Sichuan Province (Grant No. 14TD0013) in China, and the U. S. National Science Foundation (Grant CHE-1057466).

Supporting Information. Tables $\mathrm{S} 1$ to $\mathrm{S} 21$ : Harmonic vibrational frequencies (in $\mathrm{cm}^{-1}$ ) and infrared intensities (in parentheses, in $\mathrm{km} / \mathrm{mol}$ ) for the eight lowest singlet structures of $\left(\mathrm{Me}_{2} \mathrm{C}_{2} \mathrm{P}_{2}\right)_{2} \mathrm{Mn}_{2}(\mathrm{CO})_{n} \quad(n=6,5,4,3)$; Table S22: Cartesian coordinates for the nineteen lowest energy structures of $\left(\mathrm{Me}_{2} \mathrm{C}_{2} \mathrm{P}_{2}\right)_{2} \mathrm{Mn}_{2}(\mathrm{CO})_{n}(n=6,5,4,3)$; Table S23 to S26: Total energies ( $\mathrm{E}$, in hartree), relative energies $(\Delta \mathrm{E}$, in $\mathrm{kcal} / \mathrm{mol})$, and $\mathrm{Mn}-\mathrm{Mn}$ distances (in $\AA$ ) for the eight lowest energy structures of $\left(\mathrm{Me}_{2} \mathrm{C}_{2} \mathrm{P}_{2}\right)_{2} \mathrm{Mn}_{2}(\mathrm{CO})_{n}(n=6,5,4,3)$; Tables $\mathrm{S} 27$ to S30: Harmonic $v(\mathrm{CO})$ vibrational frequencies (in $\mathrm{cm}^{-1}$ ) predicted for the eight lowest energy $\left(\mathrm{Me}_{2} \mathrm{C}_{2} \mathrm{P}_{2}\right)_{2} \mathrm{Mn}_{2}(\mathrm{CO})_{n}(n=6,5,4,3)$ structures; Table S31: Total Energies (E, in hartree) for the mononuclear complexes $\left(\mathrm{Me}_{2} \mathrm{C}_{2} \mathrm{P}_{2}\right)_{2} \mathrm{Mn}_{2}(\mathrm{CO})_{n}(n=3,2,1)$; Table S32: Comparison of the $\left(\mathrm{Me}_{2} \mathrm{C}_{2} \mathrm{P}_{2}\right)_{2} \mathrm{Mn}_{2}(\mathrm{CO})_{3}$ results to those for the $\left(\mathrm{tBu}_{2} \mathrm{C}_{2} \mathrm{P}_{2}\right)_{2} \mathrm{Mn}_{2}(\mathrm{CO})_{3}$ molecules; B3LYP and BP86 results are also compared with that from the $\omega$ B97X-D functional with dispersion correction; Table S33: Complete references 33 and 48. 


\section{Literature References}

[1] T. J. Kealy, P. L. Pauson, Nature, 168 (1951) 1039.

[2] S. A. Miller, J. A. Tebboth, J. F. Tremaine, J. Chem. Soc., (1952) 632.

[3] E. O. Fischer, W. Hafner, Z. Naturforsch., 10b (1955) 665.

[4] R. Wolf, A.W. Ehlers, M. M. Khusniyarov, F. Hartl, B. de Bruin, G. J. Long, F. Grandjean, F. M. Schappecher, R. Pöttgen, J. C. Slootweg, M. Lutz, A. L. Spek, K. Lammertsma, Chem. Eur. J. 2010, 16, 14322.

[5] T. Weitling, G. Wolmershäuser, P. Binger, M. Regitz, Chem. Comm. (1990) 1541.

[6] R. Wolf, A. W. Ehlers, J. C. Slootweg, M. Lutz, D. Gudat, M. Hunger, A. L. Spek, K. Lammertsma, Angew. Chem. Int. Ed. 47 (2008) 4584.

[7] R. Wolf, J. C. Slootweg, A. W. Ehlers, F. Hartl, B. de Bruin, M. Lutz, A. L. Spek, K. Lammertsma, Angew. Chem. Int. Ed. 48 (2009) 3104.

[8] P. Binger, B. Biedenbach, R. Schneider, M. Regitz, Synthesis-Stuttgart (1989) 960.

[9] M. Sebastian, M. Nieger, D. Szieberth, L. Nyulászi, E. Niecke, Angew. Chem. Int. Ed. 43 (2004) 637.

[10] L. Nyulászi, Z. Benko, Top Heterocycl. Chem. 19 (2009) 27.

[11] F. W. Heinemann, S. Kummer, U. Seiss-Brandl, U. Zenneck, Organometallics 18 (1999) 2021.

[12] X. Chen, R. Jin, Q. Du, H. Feng, Y. Xie, R. B. King, Polyhedron, 65 (2013) 298.

[13] H. Wang, Y. Xie, R.B. King, H. F. Schaefer, Organometallics, 27 (2008) 3113.

[14] X. Chen, Q. Du, R. Jin, H. Feng, Y. Xie, R. B. King, New J. Chem., 35 (2011) 1117.

[15] X. Chen, R. Jin, Q. Du, H. Feng, Y. Xie, R. B. King, J. Organometal. Chem., 701 (2012) 1.

[16] X. Chen, Q. Du, R. Jin, H. Feng, Y. Xie, R. B. King, Polyhedron, 73 (2014) 146.

[17] T. Ziegler, J. Autschbach, Chem. Rev., 105 (2005) 2695.

[18] M. Bühl, H. Kabrede, J. Chem. Theory Comput., 2 (2006) 1282.

[19] M. Brynda, L. Gagliardi, P. O. Widmark, P. P. Power, B. O. Roos, Angew. Chem. Int. Ed., 45 (2006) 3804.

[20] N. Sieffert, M. Bühl, J. Am. Chem. Soc., 132 (2010) 8056.

[21] P. Schyman, W. Lai, H. Chen, Y. Wang, S. Shaik, J. Am. Chem. Soc., 133 (2011) 7977.

[22] R. D. Adams, W. C. Pearl, Y.O. Wong, Q. Zhang, M. B. Hall, J. R. Walensky, J. Am. Chem. Soc., 133 (2011) 12994.

[23] R. Lonsdale, J. Olah, A. J. Mulholland, J. N. Harvey, J. Am. Chem. Soc., 133 (2011) 15464.

[24] A. D. Becke, J. Chem. Phys., 98 (1993) 5648.

[25] C. Lee, W. Yang, R. G. Parr, Phys. Rev. B, 37 (1988) 785.

[26] A. D. Becke, Phys. Rev. A, 38 (1988) 3098.

[27] J. P. Perdew, Phys. Rev. B, 33 (1986) 8822.

[28] M. Reiher, O. Salomon, B. A. Hess, Theor. Chem. Acc. 107 (2001) 48.

[29] T. H. Dunning, J. Chem. Phys., 53 (1970) 2823.

[30] S. Huzinaga, J. Chem. Phys., 42 (1965) 1293. 
[31] A. J. H. Wachters, J. Chem. Phys., 52 (1970) 1033.

[32] D. M. Hood, R. M. Pitzer, H. F. Schaefer, J. Chem. Phys., 71 (1979) 705.

[33] M. J. Frisch, et al. Gaussian 09, Revision A.02, Gaussian, Inc., Wallingford CT, 2009.

[34] B. N. Papas, H. F. Schaefer, J. Mol. Struct. (THEOCHEM) 768 (2006) 175.

[35] L. Nyulaszi, J. Organomet.Chem. 690 (2005) 2597.

[36] J.-D. Chai, M. Head-Gordon, Phys. Chem. Chem. Phys. 10 (2008) 6615.

[37] B. S. Creaven, A. J. Dixon, J. M. Kelly, C. Long, M. Poliakoff, Organometallics, 6 (1987) 2800.

[38] X. Zhang, Q.s. Li, Y. Xie, R. B. King, H. F. Schaefer, Organometallics, 27 (2008) 61.

[39] J. V. Caspar, T. J. Meyer, J. Am. Chem. Soc. 102 (1980) 7794.

[40] R. H. Hooker, K. A. Mahmoud, A. J. Rest, Chem. Commun. (1983) 1022.

[41] A. F. Hepp, J. P. Blaha, C. Lewis, M. S. Wrighton, M. S. Organometallics 3 (1984) 174.

[42] J. P. Blaha, B. E. Bursten, J. C. Dewan, R. B. Frankel, C. L. Randolph, B. A. Wilson, M. S. Wrighton, J. Am. Chem. Soc. 107 (1985) 4561.

[43] M. D. Curtis, W. M. Butler, J. Organometal. Chem., 155 (1978) 131.

[44] R. B. King, A. Efraty, W. M. Douglas, J. Organometal. Chem., 60 (1973) $125 .$.

[45] J. Potenza, P. Giordano, D. Mastropaolo, A. Efraty, Inorg. Chem., 13 (1974) 2540.

[46] L. S. Sunderlin, D. Wang, R. R. Squires, J. Am. Chem. Soc., 115 (1993) 12060., 12060.

[47] F. Weinhold, C. R. Landis, Valency and Bonding: A Natural Bond Order DonorAcceptor Perspective, Cambridge University Press, Cambridge, England, U. K., 2005, pp. 32-36.

[48] M. J. Frisch, et al. Gaussian 03, Revision B.03, Gaussian, Inc., Wallingford CT, 2003.

[49] H. Wang, Y. Xie, R. B. King, H. F. Schaefer, J. Am. Chem. Soc. 128 (2006) 11376. 
Graphical Abstract - pictogram (for review)

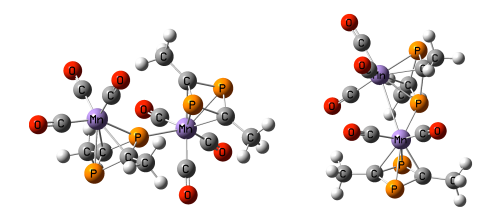

$\left(\mathrm{Me}_{2} \mathrm{C}_{2} \mathrm{P}_{2}\right)_{2} \mathrm{Mn}_{2}(\mathrm{CO})_{6} \quad\left(\mathrm{Me}_{2} \mathrm{C}_{2} \mathrm{P}_{2}\right)_{2} \mathrm{Mn}_{2}(\mathrm{CO})_{5}$

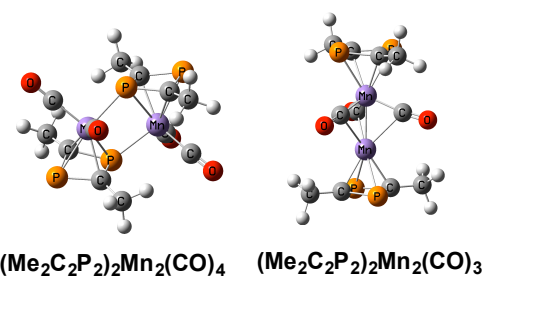

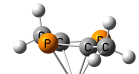

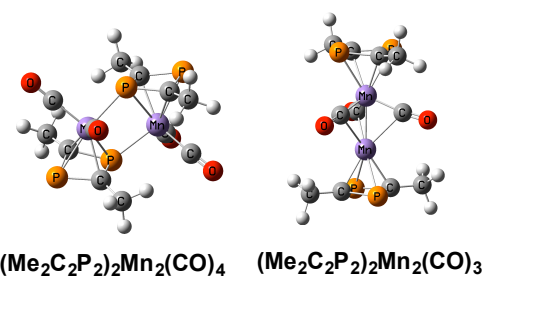

यु)

$\left(\mathrm{Me}_{2} \mathrm{C}_{2} \mathrm{P}_{2}\right)_{2} \mathrm{Mn}_{2}(\mathrm{CO})_{4} \quad\left(\mathrm{Me}_{2} \mathrm{C}_{2} \mathrm{P}_{2}\right)_{2} \mathrm{Mn}_{2}(\mathrm{CO})_{3}$

$\mathrm{C}_{2}$

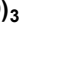

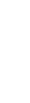

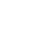

